\title{
CORRECTIVE AND DEVELOPMENT WORK OF TEACHERS WITH YOUNG CHILDREN WITH DISORDERS OF SPEECH IN THE PROCESS OF FORMING THEIR COMMUNICATIVE SKILLS
}

\author{
NATALIIA MATVEIEVA
}

\begin{abstract}
The article describes the peculiarities of the teacher's activity in the process of correction of speech disorders of younger students and their overall development. Various approaches of scientists to the content of communicative activity of a person are described, its components are defined, the stages and components of the process of formation of communicative skills of younger students with speech disorders are outlined. Emphasis is placed on the need to differentiate the concepts of "communicative competence". The author states that the development of communication skills of younger students with speech impairment is the main task not only of speech therapist, school psychologist, but also of the team of specialists of the educational institution. It is substantiated that the development of communication, speaking and communication skills is one of the prerequisites for comprehensive personality development.
\end{abstract}

Keywords: speech, communication, development, disturbance, speech therapist, correction, development environment, skills.

\section{INTRODUCTION}

Communicative competence as an important component of vital competence is considered the ability to communicate and assert self-realization of the individual, and is an indicator of his intellectual, cultural, moral, ethical, and social development. The development of language, the formation of communication skills of a person should start from childhood, when the foundations of character are laid, traits and qualities are formed, which will further regulate the behavior. In the communication process the person must have the appropriate vocabulary, be able to properly build expressions, ask questions, and listen. Being an active participant in speech, activities and communication, people enrich with new knowledge acquire fixed skills of interaction with others, learn to adapt to unusual situations, make decisions and so on. This means that the primary school should pay attention to this aspect, as successful education, upbringing and development of younger students depend on it. This is emphasized by the normative documents on education, namely: Laws of Ukraine "On Education", "On General Secondary Education", State Standard of Primary Education, Concept of the New Ukrainian School and others. The State National Education Program (Ukraine of the 21st Century), as well as the concepts of language education, presuppose the formation and development of 
a person who has a good command of the native language, skillfully uses languages as means in the process of perception or expression.

The main task under the State National Program "Education" is the formation of a linguistic personality. This will open up opportunities to unleash its makings, gifts, creativity, and talents. The updated program of the New Ukrainian School, requirements of the State standard of primary education focus on formation of those skills that are updated not only in training activities, but also during personal development, further life, choosing a career and achieving professional success etc. This demonstrates the importance of skills of communicative interaction, because such skills and abilities as to read, work with books and other sources of information, search information, think critically, work in a team or independently, solve problems and more, which are acquired in primary school - are vital to humans.

\section{ANALYSIS AND Discussion}

The problem is not new and has always been relevant, as evidenced by a large number of works of philosophers, literary critics, educators, psychologists, linguists, sociologists, etc. It was studied in various aspects, namely the features of formation of linguistic identity (A. Bohush, M. Vashulenko, T. Kotyk, L. Matsko, M. Pentylyuk, M. Muravytska, L. Palamar, O. Smolinska, N. Shumarova); problems of formation of students' reading skills (L. Ivanova, G. Koval, M. Naumchuk, etc.); factors influencing the increase of readership (M. Bakhtin, L. Vygotsky, M. Vashulenko, N. Voloshina, T. Donchenko, E. Pasichnyk, B. Stepanyshyn, V. Sukhomlinsky, N. Skrypchenko, V. Ostrogorsky, K. Ushynsky etc.). Theoretical principles of competence approach in the process of forming communicative competence studied V. Bidenko, S. Dubovik, I. Zimnya, L. Karpova, M. Krikun, A. Markova, O. Pometun, V. Slastionin, L. Khoruzha, A. Khutorsky and others. Psychological aspects of the problem of speech competence formation were discussed by M. Vasylik, L. Vygotsky, O. Leontev, L. Matsko, I. Synytsya, L. Sherba and more. The problem in the process of implementation in the educational field of inclusion - education and upbringing of children with different types of violations was discovered by I. Brushnevskaya, N. Ilyana, Z. Leniv, A. Kolupayeva, I. Martynenko, S. Sofiy, V. Tishchenko, S. Shakhovska.

An analysis of the psychological and pedagogical sources of this problem indicates that concepts such as "communicative competence" and "communicative competency" should be distinguished, where competence acts as an awareness of a person with certain concepts, phenomena, objects, and competence - a property with a value competent, that is, characterized by an appropriate level of knowledge in the process of communication and interaction with other people. The term "competence" (lat. competere - to be capable of anything) defines the ability to perform the speech activity of the individual and was initiated by the American linguist D. Himes (1972). According to the scientist, the culture of communication of personality is an indicator of the level of awareness of certain linguistic rules, as well as the presence of other knowledge, which testify to socio-cultural competence [1, p. 98]. However, language skills reflect the level of communication action and are a criterion for advanced human speech, and make up its communicative competency.

According to the State standard of primary education, communicative competence of the student is considered as formation of appropriate knowledge and skills, allowing to communicate and interact with others; independency and capability to solve main tasks in the process of learning, communication and interaction. The communicative competence of a person implies knowledge of the state and foreign languages; ability to express verbally and in writing form one's own thoughts and feelings; ability to respond in language to surrounding events and phenomena; ability to communicate. The scientist $\mathrm{Y}$. Karpenko states that "mastering the norms of literary language ... is a sign of culture ..." [6, p. 44]. Language provides the needs of society in communication, familiarization with the outside world, norms of interaction between people. In the socio-psychological aspect, the person is a biological being, an individual with inherent natural inclinations, the highest social value, and a bearer of social relations. And this indicates that the level of linguistic culture, vocabulary richness should be in line 
with the heritage of the Ukrainian nation and people. However, the issue of forming communication and of equal abilities and skills of children with speech disorders deserves special attention. This gives grounds for highlighting the main issues that need immediate resolution.

Development of communicative skills is one of the main tasks of the modern school, since students in the process of learning, playing, interacting with other students must be able to communicate, have a clear motive for sharing information in a society full of different information means. Interesting, in our opinion, is the perspective of the scientist F. Batsevych that communication is an exchange of information, experience and skills between people, whole communities, classes or groups that interact with each other. Scientists believe that communication is a part of information called bonds rights, during which the exchange of information, learning experiences, communication and other values, learning ways of communication activities [3, p. 27].

Corrective and developmental activities of the teacher - aimed at correcting existing disorders in the development of the child, pointing to the right direction, taking into account all the capabilities of the individual, natural inclinations and abilities, interests, and skills. Corrective work with students with speech disorders is a systematic logopedic correction aimed at overcoming speaking problems develop in verbal communication skills. It involves the corrective and psychological influence of the speech therapist, psychologist and teacher on the personality in combination with other positive influences by involving parents, other family members and specialists in this activity. In general, this process includes:

1) psychological correction and developmental influence on students for the purpose of development of their language and speech;

2) raising the level of knowledge of students' parents about this type of abuse and providing them with the help of specialists;

3) improving the skills of the teachers themselves in the process of working with this category of students in order to provide children with a full range of educational, developmental, correctional and other services.

The process of corrective and developmental activity of teachers with younger students who have speech impairments should be based on the tools, forms, methods of work that are necessary for the general, cultural, and mental development of students. In general, the activity of the teacher involves practical work, based on respect for the individual and its uniqueness; expanding the circle of communication of students, enriching their vocabulary (inclusion in communication with peers in the classroom, during holidays and more); involvement of students with speech impairments in various activities. The main tasks of the teaching staff of the school with younger students with speech impairment are:

1. creation of conditions for general, mental, speech development of students;

2. increasing the level of motivation of younger students to improve their own language, speech;

3. deepening students' knowledge of speech and language norms, enriching the experience of correctional educators;

4. expanding the understanding of the role of non-verbal and verbal communicative means of communication, developing speech based on non-verbal children's skills;

5. development of the individual qualities of younger students that are important in the communication process;

6. consolidation of cooperation skills, mutual support, positive attitude to different language situations;

7. development of exercises and tasks, the use of techniques and methods that are most effective in developing the skills and communication skills of children with speech disorders;

8. stimulation of all forms of communication activity of students and other [5, p. 19].

The essence of the teacher's activity lies in the development of all components of the communicative activity of the student's personality, facilitating the conditions of its adaptation and socialization, and promoting the comprehensive development. Achieving this goal is possible through the joint work of a team of specialists who develop a unified program of communication development 
of the student with speech disorders, assist in the process of socialization and communication development, correction.

The content of the development work of teachers with primary school students with speech impairment is to fill lessons, additional and corrective classes, educational activities with different techniques, methods and forms of work that allow activating the speech of children, including them in various types of communication activities. At the same time, it is necessary to use the latest technologies, non-traditional forms, game methods and situations, which are aimed at activating and consolidating communication skills, forming the necessary traits and qualities of a person for complete communication.

Noteworthy are the techniques of working with younger students, which allow you to simulate communication situations (watching movies, presentations, play-dramatization, game situations, virtual tours and more), expand the vocabulary of students and enrich their communicative experience. That is why the educational institution needs to create a developmental communication environment in which it will be comfortable to communicate with each other without exception to the students. In this context, it is necessary to organize the environment with different types of games (didactic, developmental, communicative, motor, musical, stage plays, dramatization games, etc.). That creates a relaxed atmosphere of communication and understanding between students; to put into practice the use of psychological gymnastics to train students' ability to communicate and express their opinions correctly; to organize and hold conversations, consultations. It is equally important to conduct psychological training for schoolchildren by a school psychologist with the support of teachers and parents of students. These trainings allow to get to know the children themselves, reveal their inner world and desires, help identify the students' opportunities, inclinations and abilities.

All activities of the pedagogical staff of the school in the process of developmental work with younger students with speech disorders should be based on the following basic principles, namely:

- principle of individualization of correctional and developmental work - taking into account the individual capabilities, abilities, interests of students with speech disorders; allowing to identify typical features of children with various speech disorders;

- principle of consistency and systematicity - each subsequent stage of the teacher's correctivedevelopmental activity is the next step of the previous work;

- principle of the communicative approach is to develop skills necessary for communication and interaction of the individual with speech disorders, painless adaptation and socialization in the environment of peers;

- principle of activity approach - taking into account the structure of communicative activity of students with speech disorders in the course of correction and development work with them;

- principle of integrative approach - consolidation of the acquired knowledge, formed abilities and skills of speech of students in different spheres of their life activity (in the process of studying, participation in different types of activities, extra-curricular work);

- principle of semiotic specialization of communication - designed to develop communication skills of students with reliance on their non-verbal communication abilities;

- cognitive-behavioral principle - development of complex communication skills of students (a combination of all possible means, techniques, forms, methods of correction and development work, expanding the communication experience);

- principle of modeling - alternation of models of psychological and correction influence on formation of communication skills of younger students, etc.

Involvement of younger students in various forms of communication (conversations, dialogue, reading and translation of books, play activities) aims to increase the interest of younger students in communicative interaction with other students and teachers, to satisfy their needs for communication and realization one's own ideas through verbal expression. Conducting dialogue, maintaining conversation, seeking and reproducing information serve not only to develop communication skills of younger students with speech disorders, but also to enhance their communication experience, unlock potential, and develop self-actualization skills. The process of developing students' communicative 
competence with all its components is difficult and involves diagnosing a person's level of willingness to communicate, developing skills for interaction, interest in communication and expanding the circle of communication. It includes the study of the students' inner world, establishment of their educational opportunities, communication skills, natural abilities. Therefore, the system of correction and development work with this category of students occurs in several stages (Fig. 1):

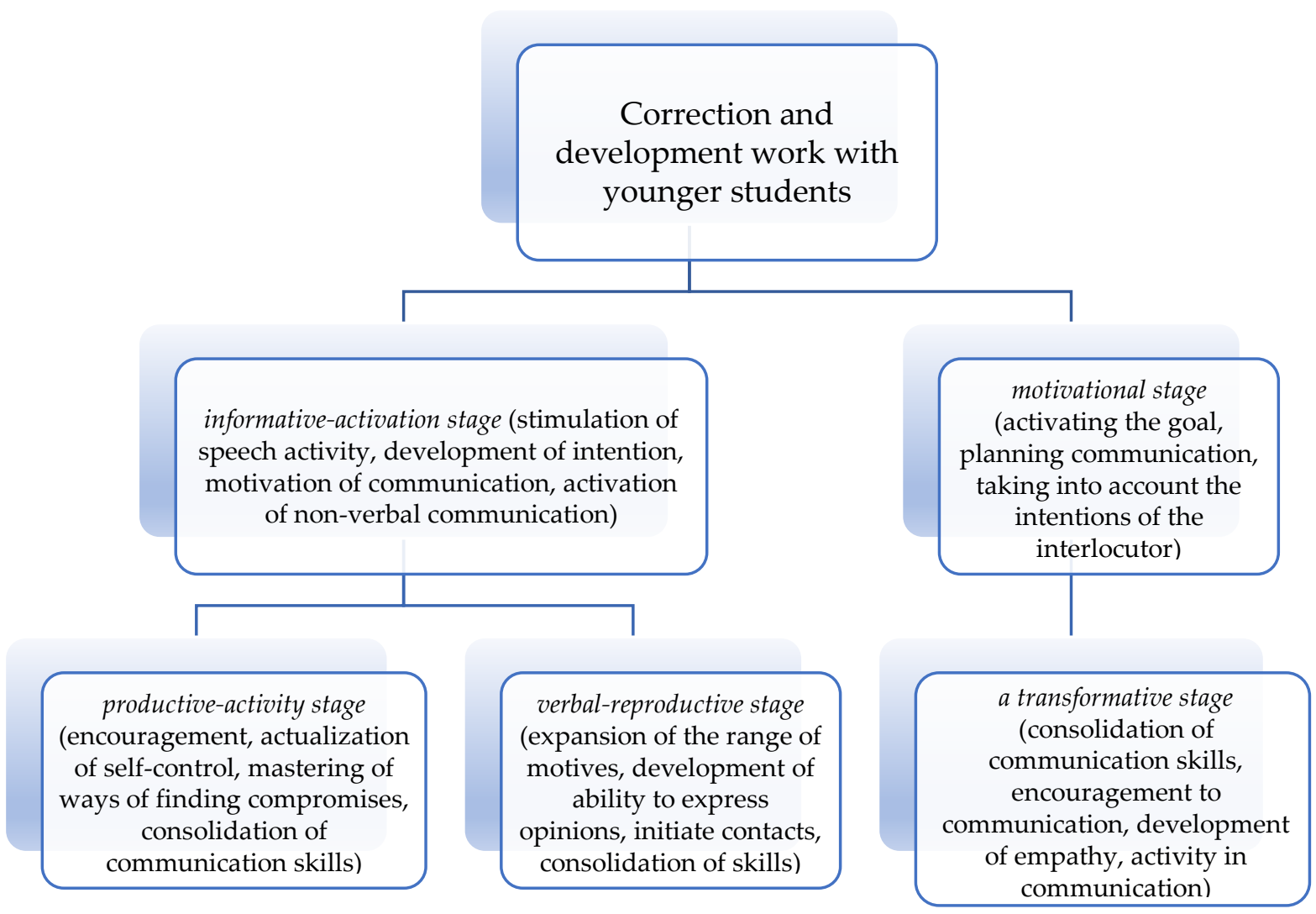

Fig. 1. The main stages of correction and developmental work of teachers with younger students with speech disorders

Each of the above stages has its own purpose and task, which allows to clearly define the techniques and content of working with students, to highlight the main shortcomings in their speech development, to outline ways to eliminate speech disorders. This is also explained by the fact that communication is a complex system that includes the needs, motives, skills and communicative actions of the individual. Since the personality in the process of communication forms its own traits and qualities, mental properties, in the absence or underdevelopment of one of the components is a decrease in the quality of communication activities, difficulties in communication, complications of socialization of personality. According to the scientist O. Losev, language performs a number of functions; serves as a means of social adaptation and social experience; reflects the norms, values and beliefs of a person [7]. A person thinks, talks, influences certain events and phenomena (people) by means of words, speech, communication, and therefore, certain disorders of speech development do not allow full development, self-realization, self-affirmation.

In terms of psychology, language and speech are means of social communication. Through speech in the process of communication can reveal the wealth of thoughts and feelings of a person. Scientist I. Bonko emphasizes that communicative competence acts as a set of personal properties, knowledge, skills that allow you to successfully implement ideas, solve problems, communicate, and act creatively. Foreign and domestic scholars, linguists, psychologists M. Vashulenko, L. Vygotsky, G. Kostyuk, J. Piaget, T. Pototska emphasize the need to develop the ability and use of all the possibilities of the word to convey one's own feelings and thoughts. Likewise, the researcher N. Didur attributes communicative competence to the socio-cultural competence of the individual and determines that it 
represents the ability to use verbal and non-verbal means of communication in different situations and social groups [4, p. 59]. As we can see, language, communication competence, social adaptation and the formation of social interaction skills are closely interrelated and influence one another. That is why the development of communication skills of students with speech impairment is one of the main tasks in the process of corrective and developmental work with them.

\section{CONCLUSIONS}

Our research has shown that speech disorders of primary school students create unfavorable conditions in the process of both their adaptation to school life and learning, and their overall development. Difficulties in learning, emergence of barriers to communication and the creation of friendly relationships, inability to put into practice what is desirable are a small list of what can be the result of indifference to speech disorders of students, avoiding their overcoming in school practice. Corrective and developmental work with younger students with speech impairments involves replacing lost communication opportunities, replacing them with others, restoring language opportunities, and correcting students' speech and communication errors. The teacher's activity system includes a number of measures aimed at solving the basic tasks of communicative personality development; alternation of different activities, techniques, methods and forms of work of teachers and students, which will result in the achievement of the didactic goal.

\section{REFERENCES}

[1] Azymov E.H. Novi slovar metodycheskykh termynov y poniatyi (teoryia y praktyka obuchenyia yazikam). YKAR, Moskva, 2009. (in Russian)

[2] Aktualni problemy korektsiinoi pedahohiky, psykholohii ta reabilitatsii: Materialy I Vseukrainskoi studentskoi naukovo-praktychnoi konferentsii, Sumy, 14.02.2017, FOP Tsoma S.P., Sumy, 2017. (in Ukrainian)

[3] Batsevych F.S. Osnovy komunikatyvnoi linhvistyky. Akademiia, Kyiv, 2004. (in Ukrainian)

[4] Didur N.A. Skladovi sotsiokulturnoi kompetentnosti maibutnoho vchytelia pochatkovoi shkoly. In: Psykholohiia i pedahohika $v$ systemi suchasnoho humanitarnoho znannia XXI stolittia: Zbirnyk tez naukovykh robit uchasnykiv Mizhnarodnoi naukovo-praktychnoi konferentsii, 9-10.12.2016, Kharkiv, 2016, 57-60. (in Ukrainian)

[5] Martynenko I.V. Komunikatyvnyi treninh dlia doshkilnykiv z porushenniamy movlennia: navchalnometodychnyi posibnyk. Ranok, Kharkiv, 2018. (in Ukrainian)

[6] Karpenko Y. Vstup do movoznavstva, 2-he vyd. Kyiv, 2009. (in Ukrainian)

[7] Losev A.F. Bitye - ymia - kosmos. Mysl', Moskva, 1993. (in Russian)

[8] Paradis J, Crago M, Genesee F, Rice M. French-English Bilingual Children With SLI. How Do They Compare With Their Monolingual Peers? Journal of Speech Language and Hearing Research, 46 (1) (2003), 113-127. doi: 10.1044/1092-4388(2003/009)

[9] Paradis J. Bilingual children with specific language impairment: Theoretical and applied issues. Applied Psycholinguistics, 28 (3) (2007), 551-564. doi: https://doi.org/10.1017/S0142716407070300

Address: Nataliia Matveieva, Vasyl Stefanyk Precarpathian National University, 57, Shevchenko Str., IvanoFrankivsk, 76018, Ukraine.

E-mail: nataliematveieva@gmail.com

Received: 05.01.2020; revised: 12.02.2020. 
Матвеєва Наталія. Корекційно-розвивальна робота учителів 3 молодшими школярами 3 порушеннями мовлення у процесі формування їх комунікативних умінь і навичок. Журнал Прикарпатського університету імені Василя Стефаника, 7 (1) (2020), 64-70.

У статті розкрито особливості діяльності вчителя у процесі корекції мовленнєвих порушень молодших школярів та педагогічного супроводу їх загального розвитку. Описано різні підходи науковців до змісту комунікативної діяльності особистості, визначено їі складові, окреслено етапи та складові процесу формування комунікативних умінь та навичок у молодших школярів 3 мовленнєвими порушеннями. Акцентовано на необхідності диференціації понять “комунікативна компетенція" та “комунікативна компетентність". Автор стверджуе, що формування комунікативних умінь і навичок молодших школярів із порушеннями мовлення є основним завданням не дише вчителя-логопеда, шкільного психолога, а й команди фахівців закладу освіти. Обгрунтовано, що розвиток умінь та навичок комунікації, мовлення та спілкування складає одну з передумов всебічного розвитку особистості. Автором доведено, що порушення мовлення в учнів початкової шкоди створюють також несприятливі умови у процесі їх адаптації до умов шкільного життя. Труднощі в навчанні, виникнення бар'єрів у спілкуванні та налагодження належних взаємин, діалогічне навчання, неможливість повною мірою втілити в практику освітні цілі - все це наслідки байдужості, нехтування чи небажання здійснювати психолого-педагогічний супровід, корекційно-розвивальну роботу щодо виправлення мовних розладів учнів. Йдеться не лише про відновлення так званих мовних можливостей та виправлення комунікативних помилок школярів, а про системну діяльності вчителя, що включає низку заходів, спрямованих на вирішення основних завдань комунікативного розвитку особистості; зміну різних видів діядьності, прийомів, методів і форм роботи заради створення розвивального освітнього середовища в закладі загадьної середньої освіти.

Ключові слова: мовлення, комунікація, спілкування, розвиток, порушення, логопед, корекція, розвивальне середовище, уміння, навички. 